\title{
Optimizing the Biodegradation of 3,4-Dichlorobenzoic Acid by Corynebacterium jeikeium
}

\author{
Ali Abdallah Alqudah ${ }^{1}$, Khaled Ahmed Tarawneh ${ }^{2}$, Ibrahim Khaled Alkafaween ${ }^{3} \&$ Shahbudin Bin Saad ${ }^{1}$ \\ ${ }^{1}$ Department of Biotechnology, International Islamic University Malaysia, Malaysia \\ ${ }^{2}$ Department of Biology, Mutah University, Jordan \\ ${ }^{3}$ Microbiology Department, Taif University, Saudi Arabia \\ Correspondence: Ali Abdallah Alqudah, Department of Biotechnology, International Islamic University \\ Malaysia, Malaysia. E-mail: alqudah45@yahoo.com
}

$\begin{array}{lc}\text { Received: March 11, } 2014 & \text { Accepted: April 22, } 2014 \quad \text { Online Published: May 28, } 2014 \\ \text { doi:10.5539/ijb.v6n3p54 } & \text { URL: http://dx.doi.org/10.5539/ijb.v6n3p54 }\end{array}$

\begin{abstract}
Chlorinated benzoic acids (CBA) have been intentionally released to the environment due to their use in agriculture as herbicides or pesticides, or unintentionally because they are common metabolites in the aerobic transformation of many chlorinated pollutants. The biodegradation of 3,4-dichlorobenzoic acid compound was investigated by using Corynebacterium jeikeium bacteria, which was isolated from Petra wastewater plant in Jordan. 3,4-dichlorobenzoic acid compound (3,4-DCBA) was used as a sole carbon and energy source in minimal salt media (MSM). 3,4-DCBA was the most degradable compound among the Chlorobenzoic acid compounds tested by this bacteria. Different conditions such as substrate concentration, temperature, $\mathrm{pH}$, agitation rate, carbon starvation and carbon adaptation were used to obtain optimal Biodegradation. The optimal conditions for the biodegradation were $3 \mathrm{mM}$ as substrate concentration and the culture conditions were also showed a significant impact on the ability of these cells to remove 3,4-DCBA. The optimum solution, temperature and agitation rate were $7.5,37^{\circ} \mathrm{C}$ and $150 \mathrm{rpm}$, respectively. Adaptation of the cells to 3,4-DCBA for $24 \mathrm{hr}$ and $48 \mathrm{hr}$ and cells starvation for $24 \mathrm{hr}$ and $48 \mathrm{hr}$ increased the initial degradation rate. The degradation ability was monitored through disappearance of the substrate from the medium and the measuring the accompanying chloride release. Corynebacterium jeikeium dioxygenases were physiologically induced by 3,4-DCBA compound. They were analyzed for both ortho or meta ring-cleavage of this aromatic compound. Only 1,2-dioxygenase activity was detected which mean that the cleavage is through the ortho pathway. This microorganism can be a valuable and promising candidate for use in the biotreatment of wastewater samples contaminated with 3,4-DCBA.
\end{abstract}

Keywords: biodegradation, carbon source, Corynebacterium jeikeium, 3, 4-dichlorobenzoic acid

\section{Introduction}

Developments in science and technology intercalate hazardous pollutants which have increased the amount of aromatic compounds released into the environment. These aromatic compounds are encountered naturally as compounds such as lignin, amino acids and tannin. Other sources of aromatic compounds include those produced from human activities such as agriculture (insecticides, herbicides, swine waste), domestic sources (sewage sludge), and industry (solvents, wood preservatives, detergents, oil) (Yi et al., 2000). The presence of these aromatic compounds in the environment presents significant problems, such as; they present a challenge to wastewater treatment plants, and they pollute groundwater and surface water (Altenschmidt et al., 1993). The most effective and economic way to clean up contaminated soil or groundwater in situ is biodegradation, provided that all contaminants (aliphatic or aromatic compounds) are mineralized in this process.

Chlorinated benzoic acids (CBA) have been intentionally released to the environment due to their use in agriculture as herbicides or pesticides, or unintentionally because they are common metabolites in the aerobic transformation of many chlorinated pollutants, including polychlorinated biphenyls (PCBs), and alkyl benzenes. In order to overcome these adverse effects, some technologies capable of breaking down these compounds have been developed by engineers. One technology, which uses aerobic conditions in which oxygen is the electron acceptor, is simply a metabolism of aromatic compounds by microorganisms. During this aerobic metabolism of 
aromatic compounds, the microorganisms use molecular oxygen to hydroxylate aromatic compounds and to perform oxidative cleavage of the aromatic ring (Lee et al., 2004). Over the past 30 - 40 years the microbial consortia have been challenged to evolve metabolic pathways to assimilate toxic chemicals released into the environment. A huge number of bacterial and fungal genera possess the ability to degrade organic pollutants and these microorganisms are of particular relevance for the biodegradation of such compounds and are exemplarily described with reference to the degradation of aliphatic and aromatic hydrocarbons as well as their chlorinated derivatives. The most rapid and complete degradation of the majority of pollutants is brought about under aerobic conditions (Krooneman et al., 2000). The first dechlorination step of 3,4-DCB is catalyzed by the 4-CB dehalogenase, while a soluble dehalogenase was responsible for dechlorination of 3-C-4-OHB. Both enzymes were inducible by the respective chlorinated substrates. 3-Chloro-4-hydroxybenzoate served as a pseudosubstrate for the 4-hydroxybenzoate monooxygenase by effecting oxygen and NADH consumption without being hydroxylated 3,4-DCB metabolism is poorly understood. The pathway for 2,4-dichlorobenzoate presumably involves a hydrolytic dehalogenation of the 4-chloro substituent, while the ortho-chlorine is reductively removed (van den Tweel et al., 1986).

To improve the efficiency of biological treatment of municipal wastewater, including in vitro degradation, the present study focused on the optimization of biodegradation process using Corynebacterium jeikeium. This study conducted to optimize the best bacterial growth conditions such as: $\mathrm{pH}$, temperature, different concentrations of substrate, agitation rate, starvation and adaptation. In addition, to detect the existence of dioxygenases enzyme to determine which type of pathways the bacteria follow it. Corynebacterium jeikeium has already been isolated from Petra wastewater treatment plant located in Jordan.

\subsection{Materials and Methods}

\subsection{Bacterial Strain}

Corynebacterium jeikeium bacterium was isolated from the wastewater treatment plant of Petra City which is located in southern Jordan. Its morphological characteristics were verified and their biochemical identity was determined using the REMEL kit (RapIDTM ONE and RapIDTM NF plus systems).

\subsection{Media and Culture Conditions}

Nutrient broth (NB) was used in this experiments. This medium consists of: (5 g) Peptic digest of animal tissue, $(5 \mathrm{~g})$ sodium chloride, $(1.5 \mathrm{~g})$ beef extract and $(1.5 \mathrm{~g})$ yeast extract dissolved in $/ 1$ liter of distilled water. $\mathrm{pH}$ was adjusted to 7.4 then autoclaving at $121{ }^{\circ} \mathrm{C}$ for $15 \mathrm{~min}$. Minimal Salts Medium (MSM) was also used to test the biodegradation of 3,4-chlorobenzoic acid as sole source of carbon and energy. One liter of MSM prepared by dissolved: (1.36 g) $\mathrm{KH}_{2} \mathrm{PO}_{4},(0.2 \mathrm{~g}) \mathrm{MgSO}_{4},(0.01 \mathrm{~g}) \mathrm{CaSO}_{2} \cdot 2 \mathrm{H}_{2} \mathrm{O},(2.43 \mathrm{~g}) \mathrm{Na}_{2} \mathrm{HPO}_{2} \cdot 2 \mathrm{H}_{2} \mathrm{O},(0.005 \mathrm{~g})$ $\mathrm{FeSO}_{4} \cdot 7 \mathrm{H}_{2} \mathrm{O},(0.5 \mathrm{~g})\left(\mathrm{NH}_{4}\right)_{2} \mathrm{SO}_{4},(0.0025 \mathrm{~g}) \mathrm{Na}_{2} \mathrm{MoO}_{2} \cdot 6 \mathrm{H}_{2} \mathrm{O}$, and $(0.0025 \mathrm{~g}) \mathrm{MnSO}_{4} \cdot \mathrm{H}_{2} \mathrm{O}$ (Hickey \& Focht, 1990).

\subsection{Starting Inoculum}

In order to avoid any discrepancy throughout the experiments adjusted starting inocula was taken in consideration. The starting inoculum was taken as $0.1 \mathrm{ml}$ of $1.4 \mathrm{OD}$ at $600 \mathrm{~nm}$.

\subsection{Determination of Growth, Degradation and Chloride Production}

The growth was monitored by measuring the absorbance at $(600 \mathrm{~nm})$ using (UV/VIS spectrometer perkinelmer lambda 25) (Monferrán et al., 2005). Different concentrations for 3,4-DCBA were monitored by measuring the maximum absorbance at $(230 \mathrm{~nm})$ using (UV/VIS spectrometer perkinelmer lambda 25). The supernatant was diluted 10 times (Marks et al., 1984) and in order to measure inorganic chloride was determined turbid metrically by measuring $\mathrm{AgCl}$ precipitation. Samples $(1 \mathrm{ml})$ were acidified with $(10 \mu \mathrm{l})$ of $10 \mathrm{NH}_{2} \mathrm{SO}_{4}$ and centrifuged at $14.000 \mathrm{rpm}$ for $5 \mathrm{~min}$ to remove material that precipitated due to acidification alone. Precipitation of $\mathrm{AgCl}$ was then measured by adding $\left(10 \mu \mathrm{l}\right.$ ) of $0.1 \mathrm{M} \mathrm{AgNO}_{3}$ (in $5 \mathrm{M} \mathrm{H}_{3} \mathrm{PO}_{4}$ ) and immediately measuring absorbance at A525 by using (UV/VIS spectrometer perkinelmer lambda 25). Chloride concentration was quantified by reference to a standard curve that was linear from 0.5 to $4 \mathrm{mM}$ (Hickey \& Focht, 1990).

\subsection{Effect of $p H$ on 3,4-Dichlorobenzoic Acid Degradation}

The effect of variation in $\mathrm{pH}(\mathrm{pH} 6,6.5,7,7.5$ and 8.0) on Corynebacterium jeikeium grown in MSM on percentage degradation of 3,4-dichlorobenzoic acid was conducted. Growth conditions, 3,4-dichlorobenzoic acid and chlorine measurement were conducted as described above except that the different $\mathrm{pH}$ values were used by buffering the solution using potassium phosphate buffer. The 3,4-dichlorobenzoic acid concentration used was 3 $\mathrm{mM}$. 


\subsection{Effect of Incubation Temperature}

To test the effect of incubation temperature as a function of time on the percentage degradation of 3,4-dichlorobenzoic acid by Corynebacterium jeikeium, different incubation temperatures were used: $25{ }^{\circ} \mathrm{C}$, $30{ }^{\circ} \mathrm{C}, 37^{\circ} \mathrm{C}$ and $42{ }^{\circ} \mathrm{C}$. Growth conditions, 3,4-dichlorobenzoic and chlorine measurement were conducted as described above except that of incubation temperature was varied; the 3,4-dichlorobenzoic acid concentration used was $3 \mathrm{mM}$.

\subsection{Effect of Aeration on 3,4-Dichlorobenzoic Degradation}

Different agitation rates using shaker with rotation $(50,100,150$, and $200 \mathrm{rpm})$ were used to assess the effect of aeration on the degradation ability of 3,4-dichlorobenzoic by Corynebacterium jeikeium. Growth conditions, 3,4-dichlorobenzoic and chlorine measurement were conducted as described above except that the agitation rates were varied. The 3,4-dichlorobenzoic concentration used was $3 \mathrm{mM}$.

\subsection{Effect of Carbon Starvation on 3,4-Dichlorobenzoic Acid Biodegradation}

Starvation experiments were conducted according to the procedure described by (Leung et al., 2005) with slight modification. Bacteria were grown on nutrient broth (NB) at $37^{\circ} \mathrm{C}, 150 \mathrm{rpm}$ and $\mathrm{pH} 7.5$ to mid-log phase prior to starvation. The cells were harvested by centrifugation $\left(5000 \mathrm{rpm}, 10 \mathrm{~min}, 4^{\circ} \mathrm{C}\right)$, washed twice with equal volumes of sterile M9 minimal medium and suspended in the same medium. The cell suspension was immediately used as the non-starved experimental control to assess 3,4-DCBA degradation by bacteria. A sub-sample of the cell suspension was C-starved in the $\mathrm{M} 9$ minimal medium at $37{ }^{\circ} \mathrm{C}$ with an agitation rate of $150 \mathrm{rpm}$ and left for $24 \mathrm{hr}$ and $48 \mathrm{hr}$. Then the carbon-starved bacteria in MSM were supplied with (3 mM) 3,4-DCBA and tested for their 3,4-DCBA degrading ability.

\subsection{Effect of Adaptation on the 3,4-Dichlorobenzoic Acid Biodegradation}

Bacteria were inoculated into minimal salt media containing $(3 \mathrm{mM})$ of 3,4-DCBA as the sole carbon source at (150 rpm, $\left.37{ }^{\circ} \mathrm{C}, \mathrm{pH} 7.5\right)$, after $(24 \mathrm{hr}$ and $48 \mathrm{hr}$ ) of incubation the cells were harvested by centrifugation and washed twice with equal volume of sterilized MSM minimal salt media. The same procedure was repeated twice and the harvested cells were suspended into (3mM) 3,4-DCBA containing MSM minimal salt media as adapted cells at $\left(150 \mathrm{rpm}, 37^{\circ} \mathrm{C}, \mathrm{pH} 7.5\right)$. One control was used, the usual experiment (non-adapted cells). The degradation was analyzed as a function of time (Khleifat, 2006).

\subsection{Pyrocatechase Assay (EC 1.13.11.1)}

For pyrocatechase (catechol-1,2-dioxygenase) assay, $(2 \mathrm{ml})$ of the reaction mixture contain: $(100 \mu \mathrm{g})$ Catechol, $(100 \mathrm{mM})$ Tris SO4 buffer $(\mathrm{pH} 7.6),(2 \mathrm{mM})$ EDTA, $(100 \mu \mathrm{M})$ 2-mercaptoethanol, $(100 \mu \mathrm{l})$ Crude extract. The formation of cis- cis muconate during the reaction was measured by the change in absorbance at $(260 \mathrm{~nm})$ after 6 min. One unit of enzyme activity was defined as the amount of enzyme that caused an absorbance change of 0.1 /min (Banta \& Kahlon, 2007).

\subsection{Metapyrocatechase Assay (EC 1.13.11.2)}

For Metapyrocatechase (catechol-2,3-dioxygenase) assay, $(2 \mathrm{ml})$ of the reaction mixture contain: $(100 \mu \mathrm{g})$ Catechol, $(100 \mathrm{mM})$ Tris $\mathrm{SO}_{4}$ buffer $(\mathrm{pH} 7.6),(100 \mu \mathrm{l})$ Crude extract. The enzyme activity was assayed spectrophotometrically by measuring the rate of 2-hydroxy semialdehyde formation at $(375 \mathrm{~nm})$ after 6 min of reaction period. One unit of enzyme activity was defined as the amount of enzyme that caused an absorbance change of $0.1 / \mathrm{min}$ (Banta \& Kahlon, 2007).

\section{Results}

\subsection{Effect of Substrate Concentration}

Corynebacterium jeikeium was capable to use 3,4-DCBA as carbon and energy source in different concentrations. The biodegradation was tested using 5 different concentrations (1, 2, 3, 4 and $5 \mathrm{mM}$ from 3,4-DCBA compound). The formation of any bacterial biomass will be a function of exhaustion of this substrates (Khleifat, 2006a, 2006b, 2006c) The maximum level of degradation was obtained with 3mM 3,4-DCBA in 20-40 hr of incubation (Table 1). The growth reaches $0.26 \mathrm{OD}$ at $600 \mathrm{~nm}$. The associated increase in degradation and growth of bacterial cells were also supported by data of chloride release (Figure 1). When using 1 or $2 \mathrm{mM}$ of 3,4-DCBA, the rate of the growth and biodegradation was smaller than that obtained with $3 \mathrm{mM}$ substrate concentration. Moreover, the consumption of 3,4-DCBA was paralleled with data results of chloride release. Raising the 3,4-DCBA concentration to 4 and $5 \mathrm{mM}$ a less degradation rate and chloride production was also observed. 
Table 1. The percentage of biodegradation of 3,4-DCBA compound at different concentrations

\begin{tabular}{ccccc}
\hline & \multicolumn{4}{c}{ Time } \\
\cline { 2 - 5 } Concentration & $20 \mathrm{hr}$ & $40 \mathrm{hr}$ & $60 \mathrm{hr}$ & $80 \mathrm{hr}$ \\
\hline $1 \mathrm{mM}$ & $25 \%$ & $15 \%$ & $48 \%$ & $60 \%$ \\
$2 \mathrm{mM}$ & $50 \%$ & $30 \%$ & $69 \%$ & $73 \%$ \\
$3 \mathrm{mM}$ & $55 \%$ & $68 \%$ & $73 \%$ & $75 \%$ \\
$4 \mathrm{mM}$ & $22 \%$ & $30 \%$ & $37 \%$ & $50 \%$ \\
$5 \mathrm{mM}$ & $10 \%$ & $15 \%$ & $19 \%$ & $23 \%$ \\
\hline
\end{tabular}

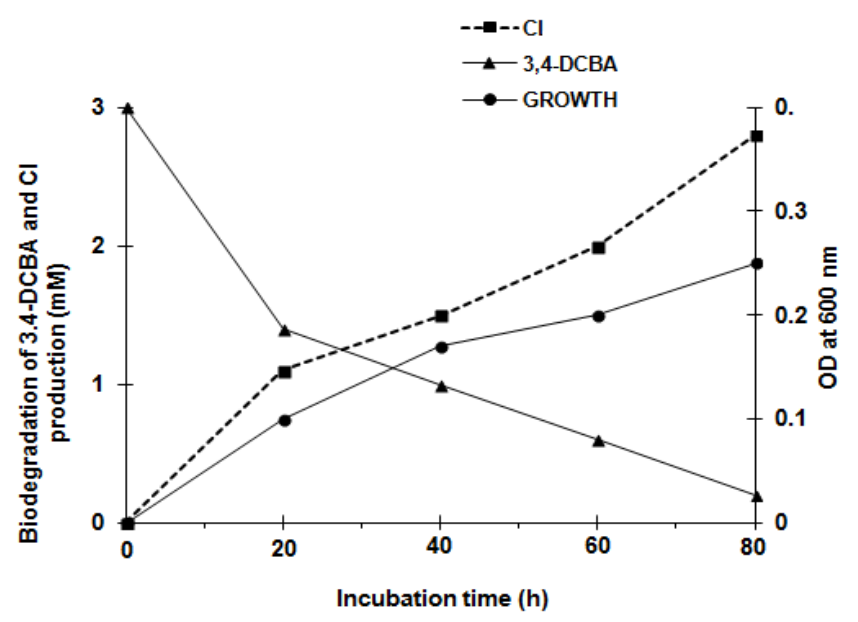

Figure 1. The Biodegradation of 3,4-DCBA, Cl productivity $(\mathrm{mM})$ and growth of bacterial cells $(C$. jeikeium) based on OD $600 \mathrm{~nm}$ measurements. The concentration of 3,4-DCBA used was (3 $\mathrm{mM})$ and its degradation was detected using 230 and $525 \mathrm{~nm}$ for 3,4-DCBA disappearance and chlorine production, respectively. Cells were grown at $37{ }^{\circ} \mathrm{C}$ incubation temperature, agitation rate of $150 \mathrm{rpm}$ and $\mathrm{pH} 7.5$

\subsection{Effect of pH, Temperature, and Aeration of Solution}

The percentages of 3,4-DCBA degradation brought about by C. jeikeium under different $\mathrm{pH}(6,6.5,7,7.5$ and 8$)$ are shown in (Table 2). The $\mathrm{pH} 7$ was considered as a control experiment. However, C. jeikeium optimally degrades the 3,4-DCBA at $\mathrm{pH} 7.5$ (Figure 2).

Table 2. The percentage of biodegradation of 3,4-DCBA compound at different $\mathrm{pH}$ levels

\begin{tabular}{ccccc}
\hline & \multicolumn{4}{c}{ Time } \\
\cline { 2 - 5 } $\mathrm{pH}$ & $20 \mathrm{hr}$ & $40 \mathrm{hr}$ & $60 \mathrm{hr}$ & $80 \mathrm{hr}$ \\
\hline 6 & $16 \%$ & $20 \%$ & $25 \%$ & $33 \%$ \\
6.5 & $18 \%$ & $22 \%$ & $26 \%$ & $39 \%$ \\
7 control & $50 \%$ & $63 \%$ & $69 \%$ & $72 \%$ \\
7.5 & $55 \%$ & $68 \%$ & $73 \%$ & $75 \%$ \\
8 & $30 \%$ & $40 \%$ & $48 \%$ & $53 \%$ \\
\hline
\end{tabular}




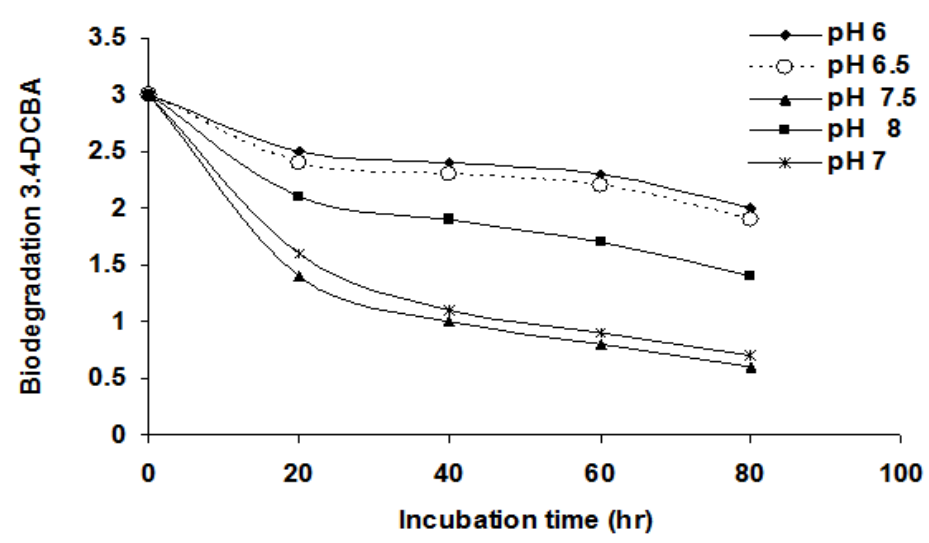

Figure 2. The Effect of $\mathrm{pH}$ of Culture Media on Biodegradation of 3,4-DCBA of bacterial cells of (C. jeikeium ). The concentration of 3,4-DCBA used was $(3 \mathrm{mM})$ and its degradation was detected using $\mathrm{OD}_{230 \mathrm{~nm}}$ for 3,4-DCBA disappearance. Cells were grown at $37^{\circ} \mathrm{C}$ incubation temperature, agitation rate of $150 \mathrm{rpm}$ and $(\mathrm{pH} 6,6.5,7$, 7.5 and 8$)$

The degradation percentage at different incubation temperatures (Table 3) showed different results at 25, 30, 37 and $42{ }^{\circ} \mathrm{C}$. The optimal temperature for cell biomass, chloride production and the initial degradation rate was $37^{\circ} \mathrm{C}$ (Figure 3).

Table 3. The percentage of biodegradation of 3,4-DCBA compound at different temperatures

\begin{tabular}{ccccc}
\hline & \multicolumn{4}{c}{ Time } \\
\cline { 2 - 5 } Temperature & $20 \mathrm{hr}$ & $40 \mathrm{hr}$ & $60 \mathrm{hr}$ & $80 \mathrm{hr}$ \\
\hline $25^{\circ} \mathrm{C}$ & $32 \%$ & $45 \%$ & $55 \%$ & $55 \%$ \\
$30^{\circ} \mathrm{C}$ & $34 \%$ & $50 \%$ & $58 \%$ & $58 \%$ \\
$37{ }^{\circ} \mathrm{C}_{\text {control }}$ & $55 \%$ & $66 \%$ & $70 \%$ & $75 \%$ \\
$42^{\circ} \mathrm{C}$ & $30 \%$ & $35 \%$ & $44 \%$ & $48 \%$ \\
\hline
\end{tabular}

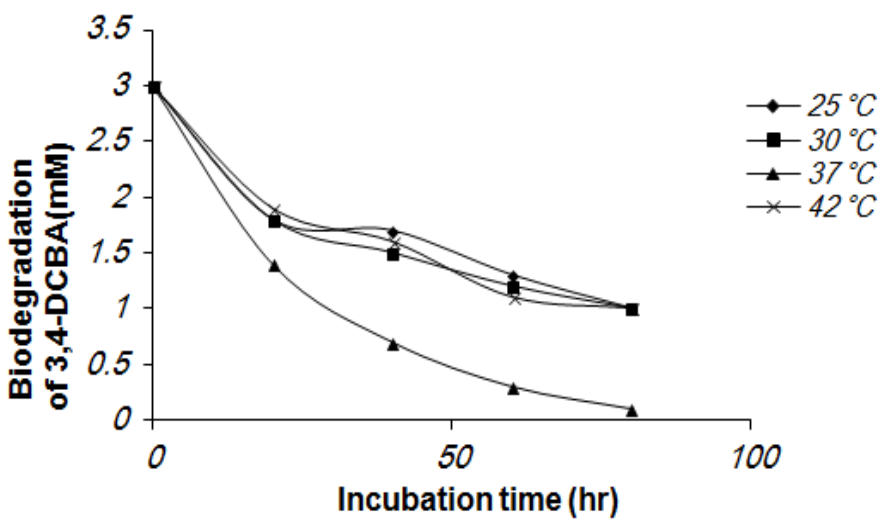

Figure 3. The effect of different Incubation Temperature $\left(25,30,37\right.$ and $\left.42{ }^{\circ} \mathrm{C}\right)$ on Biodegradation of 3,4-DCBA of bacterial cells $(C$. jeikeium). The concentration of 3,4-DCBA used was $(3 \mathrm{mM})$ and its degradation was detected using $\mathrm{OD}_{230 \mathrm{~nm}}$. Cells were grown at agitation rate of $150 \mathrm{rpm}$ and $\mathrm{pH} 7.5$

The percentages of 3,4-DCBA degradation brought about by Corynebacterium jeikeium under different agitation rate at 50,100,150 and $200 \mathrm{rpm}$ are shown in (Table 4). The effect of agitation rate was paralleled clearly on the degradation percentage (Figure 4). 
Table 4. The percentage of biodegradation of 3,4-DCBA compound at different agitation rates

\begin{tabular}{ccccc}
\hline & \multicolumn{4}{c}{ Time } \\
\cline { 2 - 5 } $\mathrm{rpm}$ & $20 \mathrm{hr}$ & $40 \mathrm{hr}$ & $60 \mathrm{hr}$ & $80 \mathrm{hr}$ \\
\hline 50 & $28 \%$ & $31 \%$ & $39 \%$ & $45 \%$ \\
100 & $30 \%$ & $35 \%$ & $46 \%$ & $50 \%$ \\
$150_{\text {control }}$ & $55 \%$ & $68 \%$ & $72 \%$ & $75 \%$ \\
200 & $18 \%$ & $22 \%$ & $30 \%$ & $36 \%$ \\
\hline
\end{tabular}

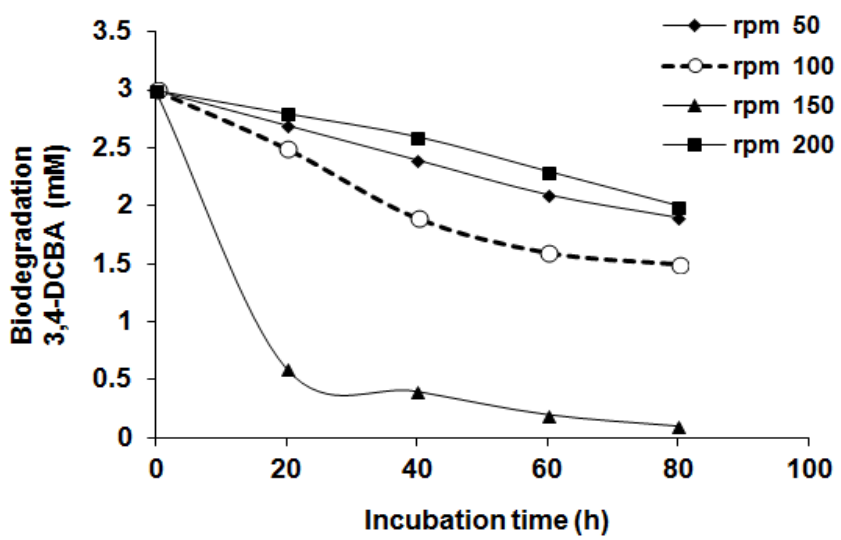

Figure 4. The Effect of agitation rate of Culture Media on Biodegradation of 3,4-DCBA of bacterial cells of (C. jeikeium ). The concentration of 3,4-DCBA used was $(3 \mathrm{mM})$ and its degradation was detected using $\mathrm{OD}_{230 \mathrm{~nm}}$ for 3,4-DCBA disappearance. Cells were grown at $37^{\circ} \mathrm{C}$ incubation temperature, $\mathrm{pH} 7.5$ and agitation rate (rpm 50, rpm 100, rpm 150 and $200 \mathrm{rpm})$

\subsection{Effect of Substrate Adaptation on Biodegradation of 3,4-DCBA}

To overcome the substrate inhibition, adapting the cell to high 3,4-DCBA concentration is one of the protocols which were used to treat aromatic compounds in wastewater (Loh \& Tan, 2000). To compare the biodegradation of 3,4-DCBA by both 3,4-DCBA pre-adapted and non-adapted Corynebacterium jeikeium cells (Figure 5).

Table 5. The percentage of biodegradation of 3.4DCBA compound at different adaptation conditions

\begin{tabular}{ccccc}
\hline & \multicolumn{4}{c}{ Time } \\
\cline { 2 - 5 } Adaptation & $20 \mathrm{hr}$ & $40 \mathrm{hr}$ & $60 \mathrm{hr}$ & $80 \mathrm{hr}$ \\
\hline $24 \mathrm{hr}$ & $53 \%$ & $56 \%$ & $61 \%$ & $68 \%$ \\
$48 \mathrm{hr}$ & $60 \%$ & $64 \%$ & $68 \%$ & $70 \%$ \\
Non Adapted & $55 \%$ & $59 \%$ & $62 \%$ & $65 \%$ \\
\hline
\end{tabular}




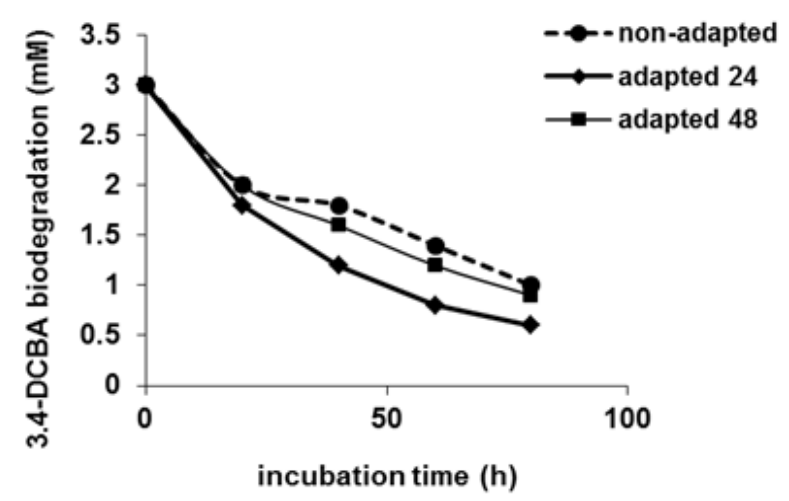

Figure 5. The effect of adaptation on 3,4-DCBA biodegradation on the bacterial cells (C. jeikeium). The concentration of 3,4-DCBA used was $(3 \mathrm{mM})$ and its degradation was detected using $\mathrm{OD}_{230 \mathrm{~nm}}$ for 3,4-DCBA

disappearance, Cells were grown at $37^{\circ} \mathrm{C}$ incubation temperature, agitation rate of $150 \mathrm{rpm}$ and $\mathrm{pH} 7.5$

\subsection{Effect of Carbon Starvation On Biodegradation of 3,4-DCBA}

Corynebacterium jeikeium cells starved for carbon source 24 and $48 \mathrm{hr}$, the degradation results were differently evaluated based on degradation percentage (Table 6) and degradation rates (Figure 6).

Table 6. The percentage of biodegradation of 3,4-DCBA compound at different starvation conditions

\begin{tabular}{ccccc}
\hline & \multicolumn{4}{c}{ Time } \\
\cline { 2 - 5 } Starvation & $20 \mathrm{hr}$ & $40 \mathrm{hr}$ & $60 \mathrm{hr}$ & $80 \mathrm{hr}$ \\
\hline $24 \mathrm{hr}$ & $59 \%$ & $66 \%$ & $72 \%$ & $74 \%$ \\
$48 \mathrm{hr}$ & $63 \%$ & $68 \%$ & $72 \%$ & $76 \%$ \\
Non Starved & $55 \%$ & $62 \%$ & $65 \%$ & $70 \%$ \\
\hline
\end{tabular}

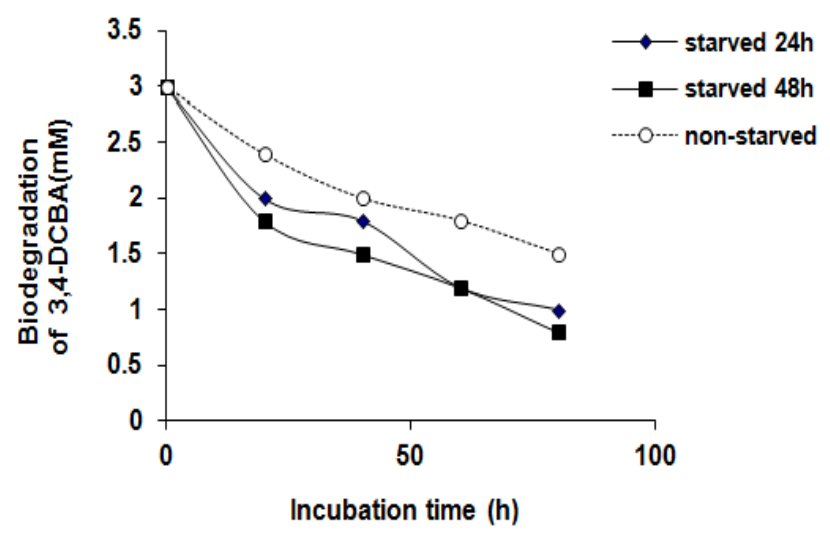

Figure 6. The effect of carbon starvation on 3,4-DCBA biodegradation of bacterial cells (C. jeikeium). The concentration of 3,4-DCBA used was $(3 \mathrm{mM})$ and its degradation was detected using $\mathrm{OD}_{230 \mathrm{~nm}}$ for 3,4-DCBA

disappearance, Cells were grown at $37^{\circ} \mathrm{C}$ incubation temperature, agitation rate of $150 \mathrm{rpm}$ and $\mathrm{pH} 7.5$

\subsection{Enzyme Assay}

To distinguish between meta and ortho pathways certain characteristic enzymes were measured, that is, $\mathrm{C}_{23} \mathrm{O}$ (2,3-catechol dioxygenase) for the meta pathway and $\mathrm{C}_{12} \mathrm{O}$ (1,2-catechol dioxygenase) for the ortho pathway. Activities of both enzymes were measured in $C$. jeikeium cells grown in the $3 \mathrm{~mm}$ 3,4-DCBA-containing minimal salt media (Figure 7). 


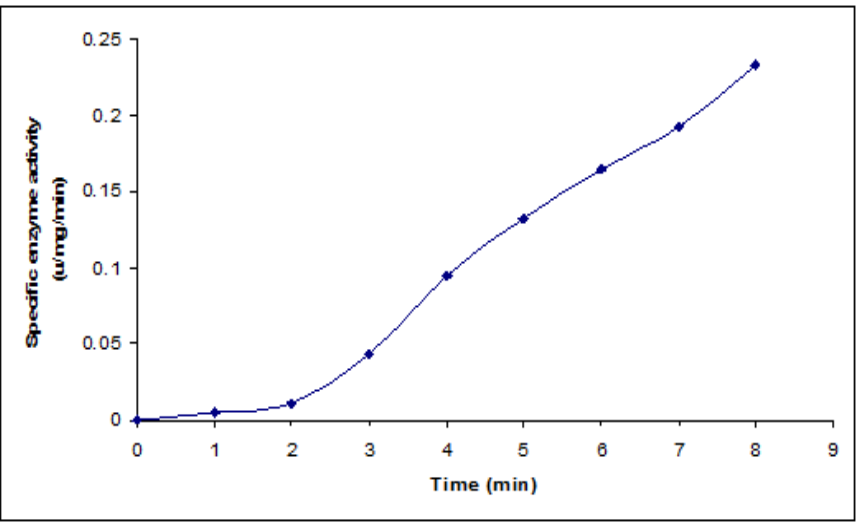

Figure 7. The activity of catechol 1,2-dioxygenase as a function of time. C. jeikeium was harvested after 24 hours of incubation in NB with $(0.5 \mathrm{mM})$ of 3,4-DCBA, at incubation temperature $\left(37^{\circ} \mathrm{C}\right)$, agitation rate of 150 $\mathrm{rpm}$ and $\mathrm{pH}$ 7.5. Enzyme assay was described in design and methodology

\section{Discussion}

Our results suggested that such biodegradation bacterium agents may be a suitable polishing agent to reduce residual contaminant levels which other chemical or physical degradation technologies cannot effectively remediate. The increasing in 3,4-DCBA degradation resulted in an increase in chloride production. However, the chloride production increase was not stiochemetricaly symmetrical to the degradation of chlorobenzoic acid compounds (Figure 1). This could be attributed to the precipitation of the $\mathrm{AgCl}$ precipitate as well as to the loss of some chloride atom in other forms not measured in the procedure used her (Tarawneh et al., 2010). Environmental factors such as $\mathrm{pH}$, temperature, and other conditions in the environment may affect the growth of $C$. jeikeium and their ability to degrade the 3,4-DCBA. In this study $C$. jeikeium could degrade 3,4-DCBA at a wide range of $\mathrm{pH}$ (Figure 2), from 6 to 8, with an optimum value of 7.5. It is possible that the enzymes for 3,4-DCBA degradation have their optimum enzymatic activity at $\mathrm{pH}$ 7.5. It was reported that optimum $\mathrm{pH}$ for the biodegradation of different aromatic compounds was different from one bacterium to another; $\mathrm{pH}$ ranges between 8 and 11 for biodegradation of phenol and catechol by the bacterium Halomonas campisalis (Alva \& Peyton, 2003).

The dependence of the rate of 3,4-DCBA degradation on temperature is illustrated in (Figure 3). Increasing the incubation temperature from $25{ }^{\circ} \mathrm{C}$ to $37{ }^{\circ} \mathrm{C}$ resulted in an increase in the degradation ability. However, further increase in the incubation temperature did not result in any further improvement; instead it caused a reduction in the percentage of degradation. In general, these bacterial cells were capable to utilize 3,4-DCBA as the sole carbon source over a wide range of incubation temperatures which is related to the metabolism of these microorganisms for the degradation process. Temperature obviously had a physiologically powerful impact on the fate of the 3,4-DCBA compound, as the $37^{\circ} \mathrm{C}$ generated the best conditions for their degradation, or this could be exclusively the outcome of a temperature effect on enzyme activities (Leven \& Schnürer, 2005). It has been reported that the temperature could play an equivalent or larger role than nutrient availability in the degradation of benzoic acid and phenol (Margesin \& Schinner, 1997). It is clear that the degradation of 3,4-DCBA for various agitations rate (Figure 4) increased when the agitation speed is increased from 50 to 150 rpm and this is due to the possibility of the 3,4-DCBA degradation process being aerobically occurred even under hypoxic conditions.

To compare the biodegradation of 3,4-DCBA by both 3,4-DCBA pre-adapted and non-adapted C. jeikeium cells, the three experiments were done under similar conditions (Figure 5). The adapted cells $(24,48) \mathrm{hr}$ degraded the 3,4-DCBA slightly quicker $(84,90 \mu \mathrm{M} / \mathrm{hr})$ than the non-adapted cells $(80 \mu \mathrm{M} / \mathrm{hr}$ ) (Figure 5). However, the time taken to accomplish this initial degradation rate $(84,90 \mu \mathrm{M} / \mathrm{hr})$ as compared with that attained by the non-adapted cells $(80 \mu \mathrm{M} / \mathrm{hr})$ was unchanged. Probably, this was due to the higher cell density resulting from simultaneous utilization of 3,4-DCBA. It was reported that acclimatization treatment would increase the degradation efficiency (Zilli et al., 1993). The microorganisms are able to adapt to the presence of toxic organic compounds by using a chain of alteration the strategies such as modification in lipid composition of cell membranes (Neumann et al., 2004). 
When our isolate was pre-starved for $24 \mathrm{hr}$ and $48 \mathrm{hr}$, the degradation ability of 3,4-DCBA had clearly commenced after a shorter acclimation period, (Figure 6) and degradation rates (Table 6). Both of two measurements showed better results as compared with the non starved cells. The starved cells for 24 and $48 \mathrm{hr}$ resulted on the 59 and $63 \%$, respectively as compared with the degradation percentage of $55 \%$ for non starved cells. This probably, results from an early expression of the 3,4-DCBA catabolic genes (Matin et al., 1999; Reardon et al., 2002; Khleifat, 2006c). This hypothesis, probably is true as long as the growth of this bacterium in the log phase was little faster than that of the non-starved cells, based on the $\mathrm{OD}_{600 \mathrm{~nm}}$. In some cases, carbon starvation in E. coli induces the expression of peptide transporter protein (carbon starvation protein A, CstA), even in the absence of their respective inducers or as a result of the induction of required degradative enzymes (Matin et al., 1999; Reardon et al., 2002). Generally, the common carbon starvation response of non differentiating Gram negative bacteria is an increase in their ability to catabolize and scavenge nutrients from the environment (Matin et al., 1999).

Chloride ions release was due to the oxygenase enzyme activities including more or less specific dioxygenases, for the halogenated compounds. In the course of our experiments, the chloride concentrations, was released as chloride ions (Qi et al., 2007; Dorn \& Knackmuss, 1978). There are two pathways for enzyme cleavage, the first one is ortho (intradiol) cleavage catechol 1,2-dioxygenase activities which was detected here for 3,4-DCBA compound investigated with different extents (Figure 7). However the second one is catechol 2,3-dioxygenase activity, which is responsible for extradiol cleavage of the meta-pathway in microorganisms that was not detected in either of our tested compound. 3,4-DCBA compound was separately added to the nutrient broth grown-cells in $0.5 \mathrm{mM}$ concentration to induce the production of enzymes. The time required to detect the maximal catechol 1,2-dioxygenase activities was shown to be 5-6 minutes (Dorn \& Knackmuss, 1978).

\section{Conclusion}

In conclusion, evidence is presented in this work for the biodegradation of 3,4-dichlorobenzoic acid (3,4-DCBA) by culture consisted of $C$. jeikeium would seem to hold promise for the removal of a higher concentration of 3,4-DCBA. C. jeikeium could be used for wastewater treatment for reduction of 3,4-DCBA from water. This degradation efficiency is affected by the condition of the medium such as the availability of oxygen, $\mathrm{pH}$, and temperature as well as other substrates. Moreover, the optimization of growth conditions resulted in the complete biodegradation of 3,4-DCBA under most of the conditions tested separately.

\section{References}

Altenschmidt, U., Oswald, B., Steiner, E., Herrmann, H., \& Fuchs, G. (1993). New aerobic benzoate oxidation pathway via benzoyl-coenzyme A and 3-hydroxybenzoyl-coenzyme A in a denitrifying Pseudomonas sp. Journal of Bacteriology, 175(15), 4851-4858.

Alva, V. A., \& Peyton, B. M. (2003). Phenol and catechol biodegradation by the haloalkaliphile Halomonas campisalis: influence of $\mathrm{pH}$ and salinity. Environmental Science \& Technology, 37(19), 4397-4402. http://dx.doi.org/10.1021/es0341844

Banta, G., \& Kahlon, R. (2007). Dehalogenation of 4-Chlorobenzoic Acid by Pseudomonas isolates. Indian Journal of Microbiology, 47(2), 139-143. http://dx.doi.org/10.1007/s12088-007-0027-5

Dorn, E., \& Knackmuss, H.-J. (1978). Chemical structure and biodegradability of halogenated aromatic compounds. Two catechol 1, 2-dioxygenases from a 3-chlorobenzoate-grown pseudomonad. Biochem. J., 174, 73-84.

Hickey, W., \& Focht, D. (1990). Degradation of mono-, di-, and trihalogenated benzoic acids by Pseudomonas aeruginosa JB2. Applied and Environmental Microbiology, 56(12), 3842-3850.

Khleifat, K. M. (2006a). Biodegradation of linear alkylbenzene sulfonate by a two-member facultative anaerobic bacterial consortium. Enzyme and Microbial Technology, 39(5), 1030-1035. http://dx.doi.org/10.1016/j.enzmictec.2006.02.007

Khleifat, K. M. (2006b). Biodegradation of phenol by Ewingella americana: Effect of carbon starvation and $\begin{array}{llll}\text { some growth } & \text { conditions. Process } & \text { Biochemistry, }\end{array}$ http://dx.doi.org/10.1016/j.procbio.2006.04.015

Khleifat, K. M. (2006c). Biodegradation of sodium lauryl ether sulfate (SLES) by two different bacterial consortia. Current Microbiology, 53(5), 444-448. http://dx.doi.org/10.1007/s00284-006-0266-4

Krooneman, J., Sliekers, A. O., Pedro Gomes, T. M., Forney, L. J., \& Gottschal, J. C. (2000). Characterization of 3 -chlorobenzoate degrading aerobic bacteria isolated under various environmental conditions. FEMS 
Microbiology Ecology, 32(1), 53-59. http://dx.doi.org/10.1111/j.1574-6941.2000.tb00698.x

Lee, S. Y., Stark, B. C., \& Webster, D. A. (2004). Structure - function studies of the Vitreoscilla hemoglobin D-region. Biochemical and Biophysical Research Communications, 316(4), 1101-1106. http://dx.doi.org/10.1016/j.bbrc.2004.02.154

Leung, K. T., Moore, M., Lee, H., \& Trevors, J. T. (2005). Effect of carbon starvation on p - nitrophenol degradation by a Moraxella strain in buffer and river water. FEMS Microbiology Ecology, 51(2), 237-245. http://dx.doi.org/10.1016/j.femsec.2004.08.007

Leven, L., \& Schnürer, A. (2005). Effects of temperature on biological degradation of phenols, benzoates and phthalates under methanogenic conditions. International Biodeterioration \& Biodegradation, 55(2), 153-160. http://dx.doi.org/10.1016/j.ibiod.2004.09.004

Loh, K.-C., \& Tan, C.-P. (2000). Effect of additional carbon sources on biodegradation of phenol. Bulletin of Environmental Contamination and Toxicology, 64(6), 756-763. http://dx.doi.org/10.1007/s0012800068

Margesin, R., \& Schinner, F. (1997). Effect of temperature on oil degradation by a psychrotrophic yeast in liquid culture and in soil. FEMS Microbiology Ecology, 24(3), 243-249. http://dx.doi.org/10.1111/j.1574-6941.1997.tb00441.x

Marks, T., Wait, R., Smith, A., \& Quirk, A. (1984). The origin of the oxygen incorporated during the dehalogenation/hydroxylation of 4-chlorobenzoate by an Arthrobacter sp. Biochemical and Biophysical Research Communications, 124(2), 669-674. http://dx.doi.org/10.1016/0006-291X(84)91607-3

Monferrán, M. V., Echenique, J. R., \& Wunderlin, D. A. (2005). Degradation of chlorobenzenes by a strain of Acidovorax avenae isolated from a polluted aquifer. Chemosphere, 61(1), 98-106. http://dx.doi.org/ 10.1128/AEM.70.4.1907-1912.2004

Neumann, G., Teras, R., Monson, L., Kivisaar, M., Schauer, F., \& Heipieper, H. J. (2004). Simultaneous degradation of atrazine and phenol by Pseudomonas sp. strain ADP: effects of toxicity and adaptation. Applied and Environmental Microbiology, 70(4), 1907-1912.

Qi, Y., Zhao, L., Ojekunle, Z. O., \& Tan, X. (2007). Isolation and preliminary characterization of a 3-chlorobenzoate degrading bacteria. Journal of Environmental Sciences, 19(3), 332-337. http://dx.doi.org/10.1016/S1001-0742(07)60054-0

Reardon, K. F., Mosteller, D. C., Rogers, J. B., DuTeau, N. M., \& Kim, K.-H. (2002). Biodegradation kinetics of aromatic hydrocarbon mixtures by pure and mixed bacterial cultures. Environmental Health Perspectives, 110 (Suppl 6), 1005.

Tarawneh, K. A., Irshaid, F., Ajlundi, I. H., Abboud, M. M., Mohammed, N. A., \& Khleifat, A. M. (2010). Biodegradation Kinetics of Four Substituted Chlorobenzoic Acids by Enterobacter aerogenes. Bioremediation Journal, 14(2), 55-66. http://dx.doi.org/ 10.1080/10889861003745676

van den Tweel, W., Ter Burg, N., Kok, J., \& De Bont, J. (1986). Bioformation of 4-hydroxybenzoate from 4-chlorobenzoate by Alcaligenes denitrificans NTB-1. Applied Microbiology and Biotechnology, 25(3), 289-294. http://dx.doi.org/ 10.1007/BF00253665

Yi, H. R., Min, K. H., Kim, C. K., \& Ka, J. O. (2000). Phylogenetic and phenotypic diversity of 4-chlorobenzoate degrading bacteria isolated frbbom soils. FEMS Microbiology Ecology, 31(1), 53-60.

Zilli, M., Converti, A., Lodi, A., Borghi, M. D., \& Ferraiolo, G. (1993). Phenol removal from waste gases with a biological filter by Pseudomonas putida. Biotechnology and Bioengineering, 41(7), 693-699. http://dx.doi.org/ 10.1002/bit.260410703

\section{Copyrights}

Copyright for this article is retained by the author(s), with first publication rights granted to the journal.

This is an open-access article distributed under the terms and conditions of the Creative Commons Attribution license (http://creativecommons.org/licenses/by/3.0/). 